\title{
The Role Optimizing of Election Observers in 2019 Elections
}

\author{
Achwan*), Sri Kusriyah $^{* *}$, and Rakhmat Bowo Suharto**) \\ *) Member of Pati Regency Election Supervisory, E-mail: achwans@gmail.com \\ ${ }^{* *}$ Faculty of Law, Universitas Islam Sultan Agung (UNISSULA) Semarang \\ ${ }^{* * *}$ ) Faculty of Law, Universitas Islam Sultan Agung (UNISSULA) Semarang
}

\begin{abstract}
.
This study aims to analyze the role of monitoring and optimizing the role of election observers. The specification of this research is analytical descriptive with socio-legal approach method. The method of collecting data is by interviewing and analyzing data from laws and regulations, research results, scientific works and relevant books. The results of this study indicate that election monitoring plays an important role in the quality of elections, namely complementing the limitations of Bawaslu in terms of the number of supervisory personnel and the breadth of the scope of its supervision, as a form of public participation, as an election control institution, as part of citizen political education and as a balance between election organizers. . To optimize the role of election observers, this can be done by: registration for accreditation is carried out at the beginning of the stages, election monitoring is carried out at all stages, the need for mastery and understanding of all election regulations, the need for sources of funds other than member fees such as budget assistance from the government or in collaboration with donor agencies that not affiliated with any election contestants or political parties,

Keywords: Election; General; Observers; Quality.
\end{abstract}

\section{Introduction}

Elections are an instrument or means to implement democracy, even in many democratic countries, elections are considered a symbol as well as a benchmark for democracy. ${ }^{1}$ Election according to Act No. 7 of 2017 is a means of people's sovereignty to elect members of the DPR, DPD members, President and Vice President, and DPRD members, which are carried out directly, publicly, freely, secretly, honestly and fairly in the Unitary State of the Republic of Indonesia based on Pancasila and the 1945 Constitution. In a democratic country, elections are very important because according to Muhammad AS Hikam as quoted by Nur Muhammad $^{2}$ related to three main functions, namely: political legitimacy, changing political elites, and political education.

Elections, according to Achmad Sulchan, ${ }^{3}$ means realizing people's sovereignty within the framework of people's participation in running the state government, not only aiming to elect representatives who will sit in a

\footnotetext{
${ }^{1}$ Saldi Isra and Khairul Fahmi, 2019, Pemilihan Umum Demokratis: Prinsip-Prinsip dalam Konstitusi Indonesia, PT RajaGrafindo Persada, Depok, p. 11

${ }^{2}$ Nur Muchammad and Munsharif Abdul Chalim, 2019, "Analysis of Criminal Liability Crime of Legislative Elections (Case Study Legislative Elections in Semarang)", Jurnal Daulat Hukum, Volume 2 issue 1, March 2019, p. 83,http://jurnal.unissula.ac.id/index.php/RH/ article/view/4210/2916 ${ }^{3}$ Sri Herlina and Umar Ma'ruf, 2019, "Law Enforcement Against Elections Crime During Electoral Campaign 2019 (Case Study In Bawaslu of Banjarmasin City)", Jurnal Daulat Hukum, Volume 2 issue 3, September 2019, p. 299, http://jurnal.unissula.ac.id/index.php/RH/ article/view/5656/3381
} 
deliberative/representative institution, but also a means to realize the preparation of the state's livelihood.

The legal framework for elections in Indonesia recognizes two electoral supervisory actors. The first is election supervisors who are given positions and tasks by the state which are then translated as election supervisors. Second, election supervisors who come from the community who are not given positions and assignments by the state are then interpreted as election observers. ${ }^{4}$

Election observers as referred to in Article 1 point 5 of PerBawaslu Number 4 of 2018 concerning Election Monitoring are non-governmental organizations, legal entities, monitoring institutions from abroad, overseas election institutions, and representatives of friendly countries in Indonesia, as well as individuals who have registered with Bawaslu and have obtained accreditation from Bawaslu. Meanwhile, election monitoring according to Article 1 point 6 is an activity carried out by election observers to monitor the implementation of the stages of organizing elections. To ensure transparency and increase credibility, the legal framework for elections must ensure that election observers can monitor all stages of the electoral process. ${ }^{5}$

In the 2019 Election, Election Observers underwent regulatory changes. If the previous election was based on Article 234 paragraph (1) of Act No. 8 of 2012, Article 174 paragraph (1) of Act No. 42 of 2008 and Article 123 paragraph (3) of Act No. 1 of 2015 Election observers must obtain accreditation from the KPU. However, in the 2019 Election, based on Article 436 paragraph 1 of Act No. 7 of 2017, Election Observers must be registered by Bawaslu.

Since the legality of election observers shifted from KPU to Bawaslu, the number of registered observers has increased sharply, at least that's what happened in Central Java. Because, in the 2014 election, it seems that there are no election monitoring institutions registered in Central Java. ${ }^{6}$

There are two types of Election Monitoring Institutions in Central Java. The first is a local organization in Central Java that has registered as observers, as many as 18 institutions. The second is election observers who are organizationally registered at the central level but their administrators or members in the regions carry out election monitoring activities, as many as 15 institutions. ${ }^{7}$

Interestingly, from 18 monitoring institutions in Central Java, 12 of them came from Pati Regency, namely: Luber Pemantau Election, Demang Pemantau Election, Kendeng Pemantau Election, Perkumpulan Keris Pemantau Election, Cendana Pemantau Election, Mawar Pemantau Election, Bintang Pemantau Election, Arjuna Pemantau Election, Jagalabilawa Pemantau Election, Srikandi Pemantau Election, Bulan Pemantau Election, and Pena Pemantau Election.

\footnotetext{
${ }^{4}$ Gunawan Suswantoro, 2016, Mengawal Penegak Demokrasi: Dibalik Tata Kelola Bawaslu \& DKPP, Erlangga, p. 110-111

5International IDEA, 2002, Standar-standar Intrenasional untuk Pemilihan Umum: Pedoman Peninjauan Kembali Kerangka Hukum Pemilu, SE 10334 Sdtockholm, Sweden, p. 97, url: https://www.idea.int/sites/default/files/ publications/standar-standar-internasional-pemilihanumum-pedoman-peninjauan-kembali-kerangka-hukum-pemilu.pdf

${ }^{6} \mathrm{http}: / /$ jateng.Bawaslu.go.id/2019/04/16/pemantau-pemilu-di-jawa-tengah-reach-677-orang, accessed on June 11,2020 at 21.40 WIB

7 Ibid
} 


\section{Research Methods}

The specification of this research is analytical descriptive with socio-legal approach method. The method of collecting data is by interviewing and analyzing data from laws and regulations, research results, scientific works and relevant books. The purpose of this study is to identify and analyze the role of election monitoring on the quality of elections, as well as to identify and analyze the optimization of the role of election observers so that the next election in Pati Regency is of higher quality.

\section{Results and Discussion}

\subsection{The Role of Election Monitoring on Election Quality}

The role of election monitoring on election quality can be described as follows:

First, the presence of election observers in the midst of the limitations of Bawaslu. The limitations referred to are related to the limitations of the Supervisory Personnel. As a supervisory agency, Bawaslu must oversee all stages of the election, while the number of personnel is very limited. At the stage of updating voter data, for example, the spearhead of supervision is the Village Supervisor who is only one person in each villages, and even then without the support of secretarial personnel. At the same level, the 3 (three) PPS members are still supported by secretariat personnel. In this sub-stage, coklit conducted by PPS is assisted by coklit officers who can later be recruited to become KPPS officers. It is true that at every polling station there is a TPS Supervisor, but the TPS Supervisor is formed before the vote.

The limited number of supervisory personnel above certainly makes the workload higher, and the accuracy of the supervision is also less effective. The presence of election observers who are not limited in terms of the number of personnel will certainly greatly assist election supervisors in carrying out supervision and monitoring at all stages, so that the quality of elections will be better.

In addition, it is also related to Bawaslu supervision is very broad. In addition to supervising all stages of the election, election supervisors must also supervise almost all elements of society since the election stage begins. At the campaign stage, for example, the scope of supervision is also very broad, namely supervising ASN, TNI/Polri, village heads, village officials, BPD and so on to ensure they maintain their neutrality. In addition, they must also supervise election participants and campaign participants. Likewise, supervision of social media which of course has a very large number of accounts. The existence of election observers who participate in monitoring/supervising the election will increase the supervisory power or sharpen the supervision carried out by election supervisors.

Second, Election observers as a form of public participation. Whereas the form of public participation in elections does not actually have to be gathered in an institution, it can also be done individually. According to Samuel P. Huntington and 
Joan M. Nelson, ${ }^{8}$ participation can be individual or collective, continuous or sporadic, peaceful or violent, legal or illegal, effective or ineffective. Citizens have the right to actively participate in the country's decision-making process. ${ }^{9}$ Attending and exercising their right to vote is also a form of participation, as well as public participation in supervising the stages of the election. Article 6 paragraph (1) of Bawaslu Regulation Number 7 of 2018 states that in addition to election contestants and election observers, Indonesian citizens who have the right to vote can also submit reports of alleged election violations.

However, this form of participation will be stronger, more focused and organized if the community joins an election monitoring body. Institutionalized public participation can be ascertained to be more effective in monitoring/supervising elections. According to International IDEA (Institute for Democracy and Electoral Assistance) ${ }^{10}$ that the ideal democracy is one of the efforts to empower the common people. The existence of election observers is part of community empowerment in the election process outside the election administrator which has been regulated in the legislation.

Third. Election observers as a control agency. Whereas Election Observers and Election Supervisors are control institutions to ensure that the General Elections take place in an impartial and fair manner in accordance with the laws and regulations. The difference is that election observers are only limited to monitoring or supervising the election process and then reporting it to Bawaslu. Meanwhile, Election Supervisors have more authority than that, namely the authority to handle election violations and resolve electoral process disputes. If more citizens are involved in election monitoring, it will narrow the scope for violations, as well as the legitimacy of the election process and results will increase. According to Muntoha, ${ }^{11}$ Among the principles of democracy are supervision and control over the administration of government must be carried out and the people are given the opportunity to raise objections. This is also in accordance with one of the twelve important characteristics of the rule of law presented by Jimly Asshiddiqie, ${ }^{12}$ namely the existence of transparency and social control.

Fourth, Election observers are part of political education. That the election is not just a contest, but each stage is a vehicle for political education for citizens. Political education according to Act No. 2 of 2011 is a learning process and understanding of the rights, obligations, and responsibilities of every citizen in the life of the nation and state.

\footnotetext{
${ }^{8}$ Wawan Setiyawan and Anis Mashdurohatun, 2021, "The Reforming of Money Politics Cases In Election Law As Corruption Crime", Law Development Journal, Volume 3 Issue 3, September 2021, p. 622

9'ka Yuana Darmayanti, 2019, "Law Politics of Legislative Election", Jurnal Daulat Hukum, Volume 2 issue 2, June 2009, p. 173, http://jurnal.unissula.ac.id/index.php/RH/article/ view/5414/3341 10 International IDEA, 2018, Global State of Democracy: Mengkaji Ketahanan Demokrasi, Kirana Karya, p. xi.

11 Muntoha, 2013, Negara Hukum Indonesia Pasca Perubahan UUD 1945, Kaukaba Dipantara, First Printing, Yogyakarta, p. 5.

12 Achmad Irwan Hamzani, 2014, "Menggagas Indonesia Sebagai Negara Hukum Yang Membahagiakan Rakyatnya", Yustisia Edisi 90 September-December 2014 Edition, p. 137, url: https://jurnal.uns.ac.id/yustisia/article/view/29562
} 
Becoming part of the Election Observer is also a political education for citizens as expressed by Marita Ahdiyana ${ }^{13}$ that political education has three objectives, namely (1) to form a political personality, (2) political awareness, and (3) to form the ability to participate in politics in individuals to become political participants in a positive form.

Forming a political personality can be achieved through training, including those held by the Election Monitoring Agency before conducting monitoring while political participation is manifested in the voluntary participation of individuals in the political life of the community, one of which is joining election monitoring institutions.

And Fifth, Election Observers as a balance between election organizers. That Election observers are not part of the election organizers. In fact, its presence can be a balancing force, both when there is a sectoral ego between election organizers and when there is tension between election organizers and election participants. When all election administrators are funded by the state, the existence of election observers whose operations are self-supporting can become a moral movement that is able to move public morale so that they continue to monitor all stages of the election process.

\subsection{Monitoring Implementation}

The monitoring implementation discussed in this study are:

First, relating to the registration and accreditation of election observers. The registration of election observers can be done at the Regency/City Bawaslu or the Provincial Bawaslu. However, the administrative verification process is carried out by the RI Bawaslu to obtain an accreditation certificate. However, according to Muhammad Rofiuddin, ${ }^{14}$ in addition to administrative verification, factual verification is also necessary to ensure the credibility and validity of administrative documents. In this factual verification process, the RI Bawaslu may involve or delegate its authority to the Provincial Bawaslu and the Regency Bawaslu.

The following is data on Election Monitoring institutions in the Regency. Pati which has received an accreditation certificate from the Indonesian Bawaslu: ${ }^{15}$

Table 1

List of Election Monitoring Institutions of Pati Regency In 2019

\begin{tabular}{llll}
\hline No & $\begin{array}{l}\text { Pemantau } \\
\text { Election }\end{array}$ & Alamat & $\begin{array}{l}\text { Nama } \\
\text { Pimpinan }\end{array}$ \\
\hline 1. & $\begin{array}{l}\text { Demang } \\
\text { Pemantau } \\
\text { Election }\end{array}$ & Vill. Karangmulyo RT 01 RW & Yuliarna \\
& 01 Dist. Tambakromo, Pati & Kurniawan, ST \\
\hline 2. & Pena Pemantau & Vill. Krajan RT 05 RW 02 Vill. & Kunarti \\
\hline
\end{tabular}

${ }^{13}$ Marita Ahdiyana, 2009, Pemilu Sebagai Wahana Pendidikan Politik, Pidato Ilmiah Dies Natalis XXX STIA-AAN Yogyakarta, 13 June 2009, p. 3.

${ }^{14}$ Interview with Muhammad Rofiuddin Kordiv Public Relations and Hubal Bawaslu Central Java Province, September 29, 2020

${ }^{15}$ Bawaslu Kabupaten Pati, 2019, Dokumen Lembaga Pemantau Pemilu Tahun 2019. 


\begin{tabular}{|c|c|c|c|}
\hline & Election & $\begin{array}{l}\text { Karangrowo, Dist. Undaan, } \\
\text { Kudus }\end{array}$ & \\
\hline 3. & $\begin{array}{l}\text { Bulan Pemantau } \\
\text { Election }\end{array}$ & $\begin{array}{l}\text { St. Kunden Raya RT } 01 \text { RW } \\
01 \text { Vill. Sidokerto, Dist. Pati, } \\
\text { Pati }\end{array}$ & Aspuri \\
\hline 4. & $\begin{array}{l}\text { Kendeng } \\
\text { Pemantau } \\
\text { Election }\end{array}$ & $\begin{array}{l}\text { Vill. Tambang RT } 06 \text { RT } 04 \\
\text { Vill. Kedungwinong, Dist. } \\
\text { Sukolilo, Pati }\end{array}$ & Mukhlisin \\
\hline 5. & $\begin{array}{l}\text { Srikandi } \\
\text { Pemantau } \\
\text { Election }\end{array}$ & $\begin{array}{l}\text { Vill. Besito RT } 04 \text { RW } 07 \text { Dist. } \\
\text { Gebog, Kudus }\end{array}$ & $\begin{array}{l}\text { Mar'atul } \\
\text { Mukminah }\end{array}$ \\
\hline 6. & $\begin{array}{l}\text { Jagalabilawa } \\
\text { Pemantau } \\
\text { Election }\end{array}$ & $\begin{array}{l}\text { St. Punden RT } 04 \text { RW } 02 \text { Vill. } \\
\text { Doropayung, Dist. Juwana, } \\
\text { Pati }\end{array}$ & Sutarjo \\
\hline 7. & $\begin{array}{l}\text { Arjuna Pemantau } \\
\text { Election }\end{array}$ & $\begin{array}{l}\text { Ngelo RT } 02 \text { RW } 03 \text { Vill. } \\
\text { Karangrowo, Dist. } \\
\text { Kudus }\end{array}$ & Badrul Khoir \\
\hline 8. & $\begin{array}{l}\text { Luber Pemantau } \\
\text { Election }\end{array}$ & $\begin{array}{l}\text { Vill. Krajan RT } 02 \text { RW } 01 \text { Vill. } \\
\text { Wotan, Dist. Sukolilo, Pati }\end{array}$ & M. Faesal Zuhri \\
\hline 9. & $\begin{array}{l}\text { Bintang Pemantau } \\
\text { Election }\end{array}$ & $\begin{array}{l}\text { Vill. Slungkep RT } 03 \text { RW 01, } \\
\text { Dist. Kayen, Pati }\end{array}$ & Rustam Santiko \\
\hline 10. & $\begin{array}{l}\text { Cendana } \\
\text { Pemantau } \\
\text { Election }\end{array}$ & $\begin{array}{l}\text { Vill. Parenggan RT } 02 \text { RW 01, } \\
\text { Dist. Pati, Pati }\end{array}$ & $\begin{array}{l}\text { Muhammad } \\
\text { Chundori }\end{array}$ \\
\hline 11. & $\begin{array}{l}\text { Keris Pemantau } \\
\text { Election }\end{array}$ & $\begin{array}{l}\text { Vill. Semirejo RT } 01 \text { RW 08, } \\
\text { Dist. Gembong, Pati }\end{array}$ & Nurcholis \\
\hline 12. & $\begin{array}{l}\text { Mawar Pemantau } \\
\text { Election }\end{array}$ & $\begin{array}{l}\text { Vill. Sarirejo RT } 01 \text { RW 01, } \\
\text { Dist. Pati, Pati }\end{array}$ & $\begin{array}{l}\text { Veronica Dian } \\
\text { Puspitaningrum }\end{array}$ \\
\hline
\end{tabular}

Second, relating to guidance/training, that mentoring or training is an important activity to provide debriefing, not only related to electoral techniques and regulations but also related to strategies that need to be implemented in monitoring by Bawaslu Prov. Central Java has twice provided guidance and training for Election Observers in Pati Regency, first located at Hotel MG Setos Semarang, ${ }^{16}$ which was attended by all election monitoring institutions in Central Java, the second took place at the New Merdeka Hotel in Pati, ${ }^{17}$ although in fact if you look at the provisions in PerBawaslu Number 4 of 2018 concerning Election Monitoring there is no obligation for Bawaslu to provide guidance and training to Election Monitoring institutions.

\footnotetext{
16 Interview with Muhammad Rofiuddin Kordiv Public Relations and Hubal Bawaslu Central Java Province, September 29, 2020.

${ }^{17}$ Interview with Suyattno Kordiv. Bawaslu of Pati Regency Dispute Settlement, September 26, 2020
} 
However, according to Sutarjo, ${ }^{18}$ Mar'atul Mukminah, ${ }^{19}$ and Nurcholis, ${ }^{20}$ The guidance and training they received from Bawaslu were still lacking, they hoped to be more than that.

Third, related to the sources of funds for Election Observers, that one of the conditions that must be met by the Election Monitoring Agency to be able to carry out monitoring as referred to in Article 3 letter c of PerBawaslu Number 4 of 2018 concerning Election Monitoring is to have a clear source of funds. All election monitoring institutions in Pati stated in their statement letters that their source of funds came from voluntary contributions from their members. ${ }^{21}$ Sources of funds originating from members are felt to be inadequate for monitoring operations. Mar'atul Mukminah, ${ }^{22}$ suggested, "My input is that Bawaslu should think about funding for a monitoring team like us." In line with Mar'atul Mukminah, Rustam Effendi ${ }^{23}$ and Chundori ${ }^{24}$ also proposed the same thing, namely the existence of a budget from the central government or local government for election monitoring activities.

Fourth, the method and focus of monitoring carried out by Election Observers, that monitoring methods that can be carried out by Election Observers include (1) direct monitoring methods, for example by field monitoring, receiving complaints and interviews, and (2) indirect methods, for example by collecting data and information from Election Organizers, the government and political parties, media searches and data/information collection based on information technology through social media. ${ }^{25}$

Based on the administrative documents for accreditation registration, the Election Monitoring bodies in Pati all chose to use the direct method of monitoring elections. ${ }^{26}$ According to Sutarjo from the Election Observer Jagabilawa ${ }^{27}$ they chose this direct method because the focus of their monitoring was on the stages of voting and counting votes so that according to him this method was the most effective, namely coming directly to the polling station as a monitoring location.

Although all Election Monitoring institutions in Pati recorded their monitoring of all stages of the election in their accreditation registration documents, it turned out that the focus of their monitoring was only on the stages of voting and counting votes.

And fifth, the findings of election observers during monitoring. That The Pati Bawaslu during the 2019 Election found 8 cases of alleged violations consisting of: 1 administrative violation, 2 criminal violations and 5 other legal violations. The Pati Bawaslu also received reports of 14 cases, consisting of 1 administrative

\footnotetext{
18 Interview with Sutarjo Jagabilawa Election Observer, 19 September 2020.

${ }^{19}$ Interview with Mar'atul Mukminah Srikandi Election Observer, 18 September 2020

${ }^{20}$ Interview with Election Monitoring Nurcholis Keris, September 18, 2020

${ }^{21}$ Bawaslu of Pati Regency, 2019, Documents of the 2019 Election Monitoring Agency.

22 Interview with Mar'atul Mukminah Srikandi Election Observer, September 18, 2020.

${ }^{23}$ Interview with Rustam Effendi Keris Election Monitor, 19 September 2020.

24 Interview with Chundori, Election Monitoring Cendana, September 18, 2020.

${ }^{25}$ Dian Kartikasari, 2019, Panduan Pemantauan Bagi Pemantau Pemilu 2019, Koalisi Perempuan Indonesia Untuk Keadilan dan Demokrasi, First Edition, Jakarta: December 2018, p. 24.

${ }^{26}$ Bawaslu of Pati Regency, 2019, Documents of the 2019 Election Monitoring Agency.

${ }^{27}$ Interview with Sutarjo Jagabilawa Election Observer, 19 September 2020.
} 
violation, 13 criminal violations and 1 other legal violation. Meanwhile, there are no findings or reports for alleged violations of the code of ethics for election organizers. ${ }^{28}$

Of the 13 reports of alleged election criminal violations, 6 of them are reports from election monitoring institutions, but the six cannot be forwarded or followed up due to non-fulfillment of formal and material requirements.

\subsection{Optimizing the Role of Election Observers in Pati Regency}

To optimize the role of Election Monitoring in conducting monitoring, the following points must be considered:

First, Initial accreditation registration is carried out at the beginning of the stage. Whereas Article 5 of PerBawaslu Number 4 of 2018 provides an opportunity for Election Monitoring institutions to be able to register themselves before the stages of holding the General Election run and are closed up to 7 days before voting. Registration carried out by the Election Monitoring Agency in Pati is on average at the end of the campaign period, so the accreditation certificate issued by the RI Bawaslu is one week before the voting stage.

If this registration is carried out in the early stages of course there are many things that can be done to optimize monitoring, including: (1) more time to recruit more credible and quality members, (2) more time to equip members in trainings on elections, both regulations and technical implementation, (3) more time in collecting various data and information obtained from KPU, Government, Bawaslu, and Political Parties to support the monitoring process, (4) more time to establish communication and cooperation with all election stakeholders, (5) more time to disseminate information to the public, this is useful in receiving complaints or reports from public.

Second, monitoring focus on all stages, not only on the stages of voting and vote counting. In this study, there is a phenomenon that all Election Monitoring institutions in Pati Regency are more focused on monitoring the stages of voting, counting and recapitulation of votes, which is actually very unfortunate. In fact, they can also oversee other stages that are no less crucial, such as updating data and voter lists, registering and verifying political parties, and campaigning.

Third, the need for increased understanding of regulations. That all elements in the implementation of elections must uphold the laws and regulations as a common guideline that must be adhered to, as well as understanding the regulations governing the reporting mechanism so that reports are of higher quality is very important so that alleged violations can be followed up properly which leads to the imposition of sanctions for violators election rules.

Reflecting on the discontinuation of all reports of alleged election violations originating from Election Observers, it indicates that the understanding of the formal and material requirements for a report to be followed up has not yet been fully paid attention to by the Election Monitoring Agency in Pati.

Fourth, related to the budget. Whereas all election monitoring institutions in Pati charge all of their operational costs to member voluntary contributions. Many complaints have arisen from them, because of that the government through

28 Bawaslu of Pati Regency, 2019, Document on the Recapitulation of Handling of Election Violations in 2019. 
Bawaslu as the agency that accredits to them needs to budget funds for monitoring. In addition, observers can also seek halal budget support from donor agencies that are not affiliated with election participants.

Fifth, pay attention to monitoring methods. It would be more effective if Election Observers, apart from using direct monitoring methods, also used indirect monitoring methods such as collecting data and information from Election Organizers, political parties, or the government, as well as conducting media tracking and media monitoring.

\section{Clossing}

The conclusion in the study is that in order to optimize the role of Election Observers in Pati Regency, this can be done by: (1) Registration for accreditation is carried out before or at the beginning of the election stage. The verification process carried out by Bawaslu includes administrative and factual verification. (2) Monitoring should be carried out at all stages, not only focusing on the stages of voting and counting votes. (3) The need for mastery and understanding of all election regulations, in particular the mechanism for reporting alleged violations. (4) The need for sources of funds other than member voluntary contributions such as budget assistance from the government and/or collaboration with donor agencies that are not affiliated with election participants or any political party. (5) In monitoring, it is better to apply direct and indirect monitoring methods.

\section{References}

\section{Journals}

[1] Achmad Irwan Hamzani, 2014, "Menggagas Indonesia Sebagai Negara Hukum Yang Membahagiakan Rakyatnya", Yustisia Edition 90 September-December 2014. url: https://jurnal.uns.ac.id/yustisia/article/view/29562

[2] Ika Yuana Darmayanti, 2019, "Law Politics of Legislative Election", Jurnal Daulat Hukum, Volume 2 issue 2, June 2009. url: http://jurnal.unissula.ac.id/ index.php/RH/article/view/5414/3341

[3] Nur Muchammad and Munsharif Abdul Chalim, 2019, "Analysis of Criminal Liability Crime of Legislative Elections (Case Study Legislative Elections in Semarang)", Jurnal Daulat Hukum, Volume 2 issue 1, url: http://jurnal.unissula.ac.id/index.php/RH/article/view/4210/2916

[4] Sri Herlina and Umar Ma'ruf, 2019, "Law Enforcement Against Elections Crime During Electoral Campaign 2019 (Case Study In Bawaslu of Banjarmasin City)", Jurnal Daulat Hukum, Volume 2 issue 3, September 2019, url: http://jurnal.unissula.ac.id/index.php/RH/article/view/5656/3381

[5] Wawan Setiyawan and Anis Mashdurohatun, 2021, "The Reforming of Money Politics Cases In Election Law As Corruption Crime", Law Development Journal, Volume 3 Issue 3, September 2021

\section{Books}

[1] Bawaslu Kabupaten Pati, 2019, Dokumen Rekapitulasi Penanganan Pelanggaran Election Tahun 2019. 
[2] Dian Kartikasari, 2019, Panduan Pemantauan Bagi Pemantau Election 2019, Koalisi Perempuan Indonesia Untuk Keadilan dan Demokrasi, First Printing, Jakarta: December 2018.

[3] Gunawan Suswantoro, 2016, Mengawal Penegak Demokrasi: Dibalik Tata Kelola Bawaslu \& DKPP, Erlangga.

[4] International IDEA, 2018, Global State of Democracy: Mengkaji Ketahanan Demokrasi, Kirana Karya.

[5] Marita Ahdiyana, 2009, Election Sebagai Wahana Pendidikan Politik, Pidato Ilmiah Dies Natalis XXX STIA-AAN Yogyakarta, 13 June 2009.

[6] Muntoha, 2013, Negara Hukum Indonesia Pasca Perubahan UUD 1945, Kaukaba Dipantara, First Printing, Yogyakarta.

[7] Saldi Isra and Khairul Fahmi, 2019, Pemilihan Umum Demokratis: PrinsipPrinsip dalam Konstitusi Indonesia, PT Raja Grafindo Persada, Depok.

\section{Internet}

[1] http://jateng.Bawaslu.go.id/2019/04/16/pemantau-Election-di-jawatengah-mencapai-677-orang, accessed on 11 June 2020 at 21.40 WIB.

[2] International IDEA, 2002, Standar-standar Intrenasional untuk Pemilihan Umum: Pedoman Peninjauan Kembali Kerangka Hukum Election, SE 10334 Sdtockholm, Sweden. url: https://www.idea.int/sites/default/files/ publications/standar-standar-internasional-pemilihan-umum-pedomanpeninjauan-kembali-kerangka-hukum-Election.pdf 